\title{
IMPACT OF VITAMIN D DEFICIENCY ON FLUCTUATION OF CALCIUM AND PARATHYROID HORMONE LEVELS IN POSTMENOPAUSAL OSTEOPOROSIS
}

\author{
Tatjana Milivojac ${ }^{1}$, Nela Rašeta ${ }^{1}$, Vera Aksentić ${ }^{2}$, and Milkica Grabež \\ ${ }^{1}$ School of medicine, University of Banja Luka, Bosnia and Hrezegovina \\ ${ }^{2}$ Institute of Physical Medicine and Rehabilitation "Dr Miroslav Zotović", Banja Luka, \\ Bosnia and Herzegovina
}

\section{SUMMARY}

The primary role of vitamin $\mathrm{D}$ is regulation of calcium, phosphorus and bone metabolism. Vitamin D status assessment is based on measuring of $25(\mathrm{OH})$ D concentrations, and disorders of vitamin $\mathrm{D}$ status may be manifested as a vitamin $\mathrm{D}$ insufficiency, vitamin $\mathrm{D}$ deficiency and vitamin $\mathrm{D}$ hypervitaminosis. It is generally accepted that values above $75 \mathrm{nmol} / \mathrm{L}$ will suffice to prevent the occurrence of secondary hyperparathyroidism. Although vitamin D deficiency can be found at any age, it is most common in women with postmenopausal osteoporosis, and in older women. The aim of this study was to determine the vitamin D status, parathyroid hormone levels and calcium levels in women with newly diagnosed postmenopausal osteoporosis, and to compare the results with the same parameters observed and measured in women without osteoporosis, and to establish whether there is a connection between vitamin $\mathrm{D}$ levels and levels of other parameters. The study involved 85 postmenopausal women, all of which were screened for osteoporosis by measuring bone mineral density in the lumbar spine and hip region using DXA method. Of these, 50 women were found to have osteoporosis while 35 had regular DXA values. Our results showed a high incidence of vitamin D deficiency in postmenopausal women, with significantly higher vitamin D deficiency in women with osteoporosis. The values of parathyroid hormone were higher, and the values of ionized calcium were lower in women with osteoporosis, and there is a negative correlation between $25(\mathrm{OH}) \mathrm{D}$ and parathyroid hormone. The most common risk factors for osteoporotic fracture in postmenopausal women were early menopause and previous fracture in adulthood. Reduced levels of vitamin D in women with postmenopausal osteoporosis leads to changes in calcium and parathyroid hormone metabolism

Key Words: parathyroid hormone, postmenopausal osteoporosis, Vitamin D.

\section{INTRODUCTION}

Osteoporosis is the most common metabolic bone disease. The process is continuous and progressive, and it is considered that osteoporosis is a process that begins in youth (failure to achieve maximum density), and manifests itself in the older age (accelerated loss) (Richard et al, 2008). It is believed that $10 \%$ of the world population suffers from osteoporosis. According to the World Health Organization [WHO] this disease, as a health issue, falls in the second place, after cardiovascular disease (Panneman, Lips, Sen, \& Herings, 2004). Basically, osteoporosis is a disorder of balance between the processes of resorption and new bone formation, in favor of the absorption process, which is more intensive than the process of new bone formation and leads to reduction of bone mineral density [BMD] and bone quality (Shoback, Marcus, Bikle, \& Strewler, 2001). Osteoporosis is a "silent" disease. Bone strength, and above all the BMD [bone mineral density] is reduced over the years without any symptoms of the disease which is often manifested in the form of spine, wrist and femoral neck fractures (Feskanich, Willett, \& Colditz, 2002), even without any inducing trauma.

The largest number of the available data refers to white women, mostly in North America and Europe 
(Framingham, SOF - The study of osteoporotic fractures, which includes 9.704 American women older than 65 years, EPOS - European Prospective Osteoporosis study of 3.173 women with an average age of 62.2 years and EPIDOS study of 6.933 women older than 75 years) (Brixen, Abrahamsen, \& Kassem, 2005).

The definition of osteoporosis according to the WHO: "Osteoporosis is a metabolic bone disease, which is characterized by decreased bone strength and increased risk for fractures" (Tuck \& Francis, 2002).

Bone strength is a reflection of two main characteristics of the bone: bone quality, which refers to the bone micro architecture, bone remodeling, and microscopic damage to the existing bone tissue; BMD which is expressed in grams per unit area $\left(\mathrm{g} / \mathrm{cm}^{2}\right)$ and is a clinical, rather than the physical measure which is determined by the maximum bone density in youthpeak bone mass and bone loss with aging (Iqbal, 2000).

WHO in collaboration with the International Osteoporosis Foundation [IOF] defines osteoporosis on the basis of the degree of reduction in BMD $(t$ score expressed as $S D$ ), which is obtained by densitometry (WHO, 1994). The criteria for osteoporosis according to the WHO/IOF are in Table 1:

Looking from overall Health and economic aspect, the importance of osteoporosis lies in its way to have

TABLE 1

Criteria for the diagnosis of osteoporosis according to the WHO/IOF.

\begin{tabular}{lc}
\hline \multicolumn{1}{c}{$\mathrm{Dg}$} & $\mathrm{BMD}(t$ score $)$ \\
\hline Normal density & $\geq-1.0 \mathrm{SD}$ \\
\hline Osteopenia & -1.0 do $-2.5 \mathrm{SD}$ \\
\hline Osteoporosis & $\leq-2,5 \mathrm{SD}$ \\
\hline
\end{tabular}

Legend: Dg - diagnosis; BMD - bone mineral density.

an effect on fractures. The most serious consequence of osteoporosis is hip fracture, which always requires hospitalization, with high mortality during the first year after a hip fracture (National Osteoporosis Foundation, 2003; Siris, 2004).

In everyday practice, the diagnosis of osteoporosis, as recommended by the WHO, is achieved by measuring BMD. In addition to reduced BMD other risk factors are important too, like genetic and acquired factors, and among them, those that can be changed and those that can't be changed (Table 2).

The gold standard test for measuring BMD is based on low energy X radiation (DXA, Dual-emission $\mathrm{X}$-ray Absorptiometry, previously DEXA), where the

TABLE 2

Risk factors for osteoporotic fractures.

Non-variable risk factors

Variable risk factors

- A history of previous fracture in adult life, which is not - Smoking caused by serious trauma

- Low body weight $(<57 \mathrm{~kg})$ or $\mathrm{BMI}<19$

- A positive family history of fractures of closest relatives

- The white race

- Female sex

- The lack of estrogen

- Low intake of calcium and vitamin d

- Age

- Dementia

- Poor general health

- Alcoholism

- Frequent falls

- Inadequate physical activity

- Visually impairment

reading of BMD in expressed in $\mathrm{g} / \mathrm{cm}^{2}$ and the results are compared with the values of the bone density of healthy population aged $20-40$ years ( $t$ score expressed as $S D$ ). When deciding on treatment, patient-obtained values are compared with the mean values of bone mineral density of people of the same age ( $z$-score $S D)$. One $S D$ indicates $10 \%$ of bone mass. BMD measurements by DXA is characterized by minimal radiation, it is comfortable, fast and has a high accuracy (Ettinger, 2003; McCloskey, 2006). Patients diagnosed with osteoporosis and confirmed by DXA, can start their treatment using antiresorptive drugs (bisphosphonates), with the use of calcium and vitamin D. The latest recommendations issued by ESCE 09 is that the treatment should last at least 5 years, after which it can be paused provided patients do not 
have serious risk factors and that there has been a significant increase in BMD (Zizic, 2004).

A large number of etiological factors may lead to a decrease in bone density, but the most common form of osteoporosis is postmenopausal osteoporosis (National Osteoporosis Foundation, 2003) in which the estrogen deficiency is a major risk factor in early and the late phase of bone loss in women, since estrogens have a very favorable, antiresorptive and a discreet anabolic effect on bone tissue.

Estrogens act directly on bone cells via estrogen receptors which are present in both osteoblasts and osteoclasts (although the expression of these receptors in bone cells is weak), and indirectly via growth factors. Estrogen is: increasing synthesis of calcitriol, slowing down osteoclasts, reducing the effects of resorptive cytokines, protecting osteoblasts and reducing receptor sensitivity to PTH (Nuti et al., 2009). This form of osteoporosis is characterized by altered bone remodeling, which occurs not only due to the deficit of sex hormones, but also due to physiological reduction of calcium absorption in the intestine and the kidney, due to reduction of the synthesis of D hormone in the kidneys and bone tissue, and due to reduction in physical activity (Greiwe, Cheng, Rubin, Yarasheski, \& Semenkovch, 2001).

\section{Vitamin $\mathrm{D}$}

Vitamin D is very similar to hormones synthesized in the body from its precursors. Whether it is synthesized in the skin or ingested with the food, vitamin $\mathrm{D}$ is biologically inactive. It is subjected to hydroxylation in the liver, in position C-25 under the effect of $25 \alpha$ hydroxylase, and it becomes 25 -hydroxyvitamin $\mathrm{D}(25(\mathrm{OH}) \mathrm{D})$, which represents most of the vitamin $\mathrm{D}$ in the plasma, which is attached to the transport protein by which it is transferred to the kidneys. As the concentration of $25(\mathrm{OH}) \mathrm{D}$ depends solely on the presence of substrate (pro-vitamin intake and sun exposure), it is an appropriate measure of the amount of vitamin $\mathrm{D}$ in the body. In the kidney $25(\mathrm{OH}) \mathrm{D}$ is further metabolized by hydroxylation at position C-1 with the help of the enzyme $1 \alpha$ hydroxylase, to form an active form of the vitamin, 1,25-dihydroxyvitamin D (1.25 (OH) 2D, calcitriol or hormone D), through which it exerts most of its effects (Holick, 2007). The active form of vitamin D is released into the bloodstream and bound with the carrier protein transcalciferin, by which it is transported to the target organs, where it binds to specific vitamin D receptors [VDR] with which it exerts its effects. The kidney is the main organ in which it is converted $25(\mathrm{OH}) \mathrm{D}$ into calcitriol, but it is not the only place the synthe- sis of $1 \alpha$ hydroxylase takes place. Extrarenal synthesis of this enzyme has an important role in the immunoregulatory and autoproliferative effects of vitamin D (bone marrow, immune system, epithelial cells of the skin, breast, prostate, muscle and intestines). Extrarenal production of calcitriol is not sufficiently assessed, but it is believed that under normal conditions it does not significantly increase serum concentrations of D hormone (Bronner, 2001).

The most important stimulators of calcitriol synthesis are hypocalcaemia and hypophosphatemia. Hypocalcaemia does not cause direct stimulation of synthesis of calcitriol, rather this effect is achieved indirectly through PTH. Reduction of calcium concentration in plasma increases PTH secretion, which in turn increases the activity of $1 \alpha$ hydroxylase and synthesis of calcitriol (Bischoff-Ferrari et al., 2004). The estrogen and growth hormone $[\mathrm{GH}]$, also stimulate renal $1 \alpha$ hydroxylation. Calcitriol actively stimulates the absorption of calcium in the small intestine and thus indirectly regulates the secretion of PTH. It increases the synthesis of transforming growth factor $\beta$ (TGF- $\beta$ ), and IGF-1, increases the number of IGF-1 receptors, thereby stimulating osteoblastic proliferation and differentiation, increasing the synthesis of type I collagen and matrix proteins (osteopontin and osteocalcin), all of which are necessary for mineralization, function and metabolism of bone tissue, and thus contribute to the bone strength. It also acts on osteoclasts: indirectly through osteoblasts, and directly, suppressing the differentiation of promyelocytes into monocytes, which are the precursors of osteoclasts (Bischoff-Ferrari et al., 2005; Stevenson \& Marsh, 2007).

Vitamin D status is estimated on the basis of the concentration of $25(\mathrm{OH}) \mathrm{D}$ levels. There are many disputes in terms of optimal vitamin D status in serum (Aloia, 2001). According to Peacock-in and collaborators, until recently, the lack of vitamin $\mathrm{D}$ was defined as concentration of $25(\mathrm{OH}) \mathrm{D}$ serum in which a secondary hyperparathyroidism occurs, and in which there is a decrease in bone mass without the occurrence of hypocalcaemia or osteomalacia (Peacock, Selby, Francis, Brown, \& Hordon, 1985). Since 2005, a normal status of vitamin $\mathrm{D}$ is defined as the concentration of $25(\mathrm{OH}) \mathrm{D}>75 \mathrm{nmol} / \mathrm{L}$. Vitamin D insufficiency is defined as concentration of $25(\mathrm{OH})$ $\mathrm{D}<25 \mathrm{nmol} / \mathrm{L}$, Vitamin $\mathrm{D}$ deficiency is defined as concentration of $25(\mathrm{OH}) \mathrm{D} 25-75 \mathrm{nmol} / \mathrm{L}$ and vitamin D Intoxication is defined as concentration of $25(\mathrm{OH}) \mathrm{D}>250 \mathrm{nmol} / \mathrm{L}$ (Aloia, Talwar, Pollack, Feuerman, \& Yeh, 2006).

Vitamin D deficiency leads to defective calcium metabolism, defective osteoblastic activity, and defec- 
tive matrix mineralization and finally leads to disorders of bone mineral density. Vitamin D deficiency is one of the most common causes of secondary hyperparathyroidism, and it is considered that the value of 25 $(\mathrm{OH}) \mathrm{D}>75 \mathrm{nmol} / \mathrm{L}$ can prevent its development. As defined in 2005, there is a high percentage of women (around 60\%) with postmenopausal osteoporosis, and a lack of vitamin D (Sweet, Jeremiah, \& Galazka, 2009). Vitamin D deficiency leads to muscle disturbances, where calcitriol, by binding to the VDR of skeletal muscle cells regulates muscle contraction and relaxation, increases protein synthesis and the entry of calcium into the cell. In the situation of vitamin D deficiency there is a loss of muscle fibrils of type II and a decrease in muscle strength and increased risk of falling and fractures (Dawson-Hughes et al., 2005; Vieth \& Fraser, 2002). Optimal prevention of bone fractures in women with postmenopausal osteoporosis, in addition to the application of antiresorptive therapy, includes adequate supplementation of vitamin $\mathrm{D}$, whose unique dual effect on bone and muscle tissue increases bone mineral density, but also the prevents falls (Canalis, 2010). Nowadays it is considered that for the optimal anti-fracture value of $25(\mathrm{OH}) \mathrm{D}$ serum concentration of $100-120 \mathrm{nmol} / \mathrm{L}$ the required daily intake of vitamin $\mathrm{D} 3$ needs to be $1000 \mathrm{IU}$, if the value of $25(\mathrm{OH}) \mathrm{D}$ in the serum is 60-75 nmol/L, required daily intake of vitamin D 3 needs to be $2000 \mathrm{IU}$ if the value of $25(\mathrm{OH}) \mathrm{D}$ in the serum is $30-60 \mathrm{nmol} / \mathrm{L}$ and required daily intake of vitamin D 3 needs to be 3000 IU if the value of 25 $(\mathrm{OH}) \mathrm{D}$ in the serum is less than $30 \mathrm{nmol} / \mathrm{L}$ (Grand et al., 2005; Jackson et al., 2006). These recommendations are in line with recommendations of American osteoporosis Foundation (Cosman et al., 2014; National Osteoporosis Foundation, 2015). There is evidence that treatment with bisphosphonates should be initiated only after ensuring anti-fracture concentration of $25(\mathrm{OH}) \mathrm{D}$ serum is achieved, because otherwise their efficiency is significantly smaller (Cooper, 2006).

Testing of vitamin D status is not part of the daily routine in the diagnosis and treatment of osteoporosis. It is desirable that all patients with osteoporosis have at least one paired finding of $25(\mathrm{OH}) \mathrm{D}$ in the serum, one at the end of winter and one at the end of summer, when minimum and maximum concentration of $25(\mathrm{OH}) \mathrm{D}$ is expected. Determination of vitamin $\mathrm{D}$ status is required in patients with hypercalcaemia, hypocalcaemia, elevated PTH, hypercalciuria, hypocalciuria and in patients with a history of prior fractures (Pilipović, Branković, \& Vujasinović, 2005).

\section{Calcium and parathyroid hormone}

The human organism contains 1000-1200 grams of calcium, $99 \%$ of which is located within the bones. $88 \%$ of the total amount of calcium in bone is bound to phosphorus (Ca: $\mathrm{Pa}=2: 1) ; 1 \%$ of the total amount of calcium is contained within the body fluids in the intra- and extracellular space. Calcium requirements vary by age, sex and physiological state. The organs involved in its metabolism are bones, intestines and kidneys, all of which happens under the influence of PTH, calcitriol, sex hormones and glucocorticoids. The absorption of calcium through the intestinal epithelium occurs passively (non-saturable) and trancellular (saturable) pathway.

Calcium binding protein calbinidin D plays a key role in the transfer of calcium through the enterocytes and the latest data suggest that estrogen can stimulate this influx through cAMP. Calcium homeostasis through osteocytic membrane occurs in the process of active exchange of calcium between the extracellular fluid and bone, wherein the amount of calcium that enters the bone is equal to the amount that comes out (about $500 \mathrm{mg} /$ day), so that bone mass remains constant. Calcitriol via the VDR receptor stimulates: transcription of calbinidin (which increases calcium entry through the apical channels); Activity of $\mathrm{Ca}^{2}+$ -ATPase in the basolateral membrane and calcium transport through tubulocytes.

PTH is a hormone essential in the process of bone remodeling in the regulation of calcium levels in the blood. Its effect is exerted by binding to receptors in the membrane of osteoblasts and tubular cells of the kidneys. It stimulates mature osteoblasts, which are unable to proliferate and to produce growth factors such as FGF-2 and IGF-1, which stimulates proliferation osteoprogenitor cells that have the receptor for PTH. FGF (fibroblast growth factor) is the primary mediator of action of PTH on bone. PTH leads to the accumulation of a multilayer of osteoblasts at sites of bone formation. Regulation of syntheses and secretion of PTH with Ca ions includes the negative feedback mechanism: the reduction of calcium levels leading to increased secretion and activity of PTH, which stimulates osteoclasts (indirectly via osteoblasts) to produce cytokines which are stimulating osteoblast and osteoclast precursors (IL-1, PG E2, TNF, etc.), leading to bone resorption and release of calcium into the blood. PTH increases Ca reabsorption in the kidney, GIT absorption of Ca through stimulation of the synthesis of the $\mathrm{D}$ hormones, it increases resorption of phosphate from bones and increases excretion of phosphates. In intermittent secretion; 
PTH increases the number preosteoblasts and thus it is the most important factor in the formation of bone, while continuing high value of PTH leads to a predominance of bone resorption. Changes in the concentration of ionized calcium in the serum of $8 \%$ may lead to a triple change in PTH concentration (Lips, 2006; Stefanović, Zečević, \& Petronijević, 2009).

Aim of the paper is:

- to determine the concentration of $25(\mathrm{OH}) \mathrm{D}$, ionized and total calcium and parathyroid hormone in the blood of women with postmenopausal osteoporosis and to compare them with the values obtained in postmenopausal women without osteoporosis. To determine the frequency and degree of vitamin $\mathrm{D}$ deficiency in women with postmenopausal osteoporosis.

- to explore the association between vitamin $\mathrm{D}$ deficiency and the values of ionized serum calcium and parathyroid hormone.

- to analyze the most common risk factors for osteoporotic fractures.

\section{METHODS}

The study was conducted as a prospective study from May to December of 2010, in Institute of Physical Medicine and Rehabilitation "Dr. Miroslav Zotovic", Banjaluka.

A stratified sample $(N)$ of 85 women was created with an average age of 50-70 years.
Once densitometry was done patients were divided into two groups:

- (n) of 50 women with a BMD $t$-test $\leq-2.5 S D$ - women with newly discovered osteoporosis

- (n) of 35 women with a BMD $t$-test $\geq-1.0 S D$ - women who do not have osteoporosis.

All respondents surveyed questionnaire, which includes risk factors for osteoporotic fractures.

After the DXA, their fasting venous blood (PTH, $25(\mathrm{OH}) \mathrm{D}$ serum $\mathrm{Ca}$ ) and capillary blood (Ionized $\mathrm{Ca}$ ) was drawn.

Total Serum Ca was determined by spectrophotometry using Roche Cobas C 111, and ionized Ca was determined by potentiometric method using Roche Analyzer 9180th.

Reference range of the SCa is 2.15 to $2.55 \mathrm{mmol} / \mathrm{L}$; while reference range of $\mathrm{Ca}^{++}$is $1.05-1.35 \mathrm{mmol} / \mathrm{L}$.

Serum concentrations of PTH and $25(\mathrm{OH}) \mathrm{D}$ were determined using electrochemiluminiscent immunochemical method using Roche Elecsys 2010. Reference range of PTH is $15-65 \mathrm{pg} / \mathrm{mL}$.

The significance of the investigated parameters between groups formed on the basis of the value of $\mathrm{BMD}$, was determined using $t$-test for independent samples and using $U$ test for non-parametric comparison. Level of statistical significance was arbitrary chosen as $p<.05$.

The correlation of tested parameters with the levels of $25(\mathrm{OH}) \mathrm{D}$ in the group of women with osteoporosis, was statistically calculated using correlation test and was shown as a correlation coefficient.

TABLE 3

Descriptive analysis of the studied parameters in the group of patients (n) 50 with BMD $\leq-2.5$ SD.

\begin{tabular}{lrrrrr}
\hline \multicolumn{1}{c}{$(n) 50 \mathrm{BMD} \leq-2,5 \mathrm{SD}$} & \multicolumn{1}{c}{ Min } & \multicolumn{1}{c}{ Max } & \multicolumn{1}{c}{$M$} & \multicolumn{1}{c}{$S D$} & \multicolumn{1}{c}{$v$} \\
\hline Age & 50.000 & 70.000 & 61.540 & 5.210 & 27.190 \\
\hline Menopause & 1.000 & 30.000 & 12.340 & 5.640 & 31.820 \\
\hline 25(OH)D $(\mathrm{nmol} / \mathrm{L})$ & 10.000 & 72.660 & 26.840 & 14.690 & 215.670 \\
\hline $\mathrm{PTH}(\mathrm{pg} / \mathrm{mL})$ & 4.040 & 97.340 & 44.340 & 17.230 & 296.790 \\
\hline $\mathrm{Ca}^{++}(\mathrm{mmol} / \mathrm{L})$ & 1.100 & 1.480 & 1.310 & .060 & .003 \\
\hline $\mathrm{CaS}(\mathrm{mmol} / \mathrm{L})$ & 2.000 & 2.710 & 2.330 & .130 & .025 \\
\hline BMD L1-L4 g/ $\mathrm{cm}^{2}$ & .657 & .911 & .819 & .060 & .003 \\
\hline BMD L1-L4 $t$-test & -4.400 & -2.000 & -3.026 & .460 & .213 \\
\hline BMD NECK of L FEMUR g/ $\mathrm{cm}^{2}$ & .389 & .916 & .765 & .090 & .007 \\
\hline BMD NECK of L FEMUR $t$-test & -2.700 & -.500 & -1.759 & .560 & .319 \\
\hline
\end{tabular}

Legend: $\mathbf{n}$ - number of inhabitants; Min - mnimum; Max - maxmum; $\mathbf{M}$ - mean; SD - standard deviaton, $\mathbf{v}$ - varianca. 
Significance of differences of the most-represented risk factors between the two groups is presented in tabular form. Level of statistical significance was arbitrary chosen as $p<.05$.

\section{RESULTS}

Tables 3 and 4 show minimum and maximum values, means, standard deviations and variance for

TABLE 4

Descriptive analysis of the studied parameters in the group of patients (n) 35 with BMD $\geq-1.0$ SD.

\begin{tabular}{lrrrrr}
\hline \multicolumn{1}{c}{$(n) 50 \mathrm{BMD} \leq-2,5 \mathrm{SD}$} & \multicolumn{1}{c}{ Min } & \multicolumn{1}{c}{ Max } & \multicolumn{1}{c}{$M$} & \multicolumn{1}{c}{$S D$} & \multicolumn{1}{c}{$v$} \\
\hline Age & 50.000 & 70.000 & 59.030 & 4.790 & 23.028 \\
\hline Menopause & 1.000 & 28.000 & 7.970 & 6.370 & 40.606 \\
\hline 25(OH)D $(\mathrm{nmol} / \mathrm{L})$ & 19.570 & 74.920 & 35.670 & 10.470 & 109.580 \\
\hline $\mathrm{PTH}(\mathrm{pg} / \mathrm{mL})$ & 2.230 & 83.810 & 35.220 & 19.730 & 389.179 \\
\hline $\mathrm{Ca}^{++}(\mathrm{mmol} / \mathrm{L})$ & 1.240 & 1.560 & 1.340 & .060 & .004 \\
\hline $\mathrm{CaS}(\mathrm{mmol} / \mathrm{L})$ & 2.130 & 2.720 & 2.290 & .110 & .012 \\
\hline $\mathrm{BMD} \mathrm{L} 1-\mathrm{L} 4 \mathrm{~g} / \mathrm{cm}^{2}$ & 1.002 & 1.970 & 1.260 & .170 & .031 \\
\hline BMD L1-L4 $t$-test & -1.000 & 2.600 & .660 & .970 & .956 \\
\hline BMD NECK of L FEMUR g/ $\mathrm{cm}^{2}$ & .889 & 1.270 & 1.030 & .100 & .010 \\
\hline BMD NECK of L FEMUR $t$-test & -.080 & 2.500 & .600 & .860 & .755 \\
\hline
\end{tabular}

Legend: $\mathbf{n}$ - number of inhabitants; Min - mnimum; Max - maxmum; M - mean; SD - standard deviaton, $\mathbf{v}$ - varianca.

TABLE 5

Descriptive analysis of the studied parameters in the group of patients (n) 35 with BMD $\geq-1.0$ SD.

\begin{tabular}{lrlrll}
\hline & $F$ & $F_{c}$ & $t$ & \multicolumn{1}{c}{$t$} & \multicolumn{1}{c}{$p$} \\
\hline Age & 1.18 & 1.72 & 2.25 & 1.66 & $\mathbf{. 0 1 3}$ \\
\hline Durton of menopause & .78 & 1.72 & 3.33 & 1.66 & $\mathbf{. 0 0 1}$ \\
\hline $25(\mathrm{OH}) \mathrm{D}(\mathrm{nmol} / \mathrm{L})$ & 1.97 & 1.72 & -3.23 & 1.66 & $\mathbf{. 0 0 1}$ \\
\hline $\mathrm{PTH}(\mathrm{pg} / \mathrm{mL})$ & .76 & 1.72 & 1.78 & 1.66 & $\mathbf{. 0 3 9}$ \\
\hline $\mathrm{Ca}^{++}(\mathrm{mmol} / \mathrm{L})$ & .87 & 1.72 & -2.42 & 1.66 & $\mathbf{. 0 0 9}$ \\
\hline $\mathrm{CaS}(\mathrm{mmol} / \mathrm{L})$ & 2.09 & 1.72 & 1.31 & 1.66 & .097 \\
\hline & & & & &
\end{tabular}

Legend: $\mathbf{F}$ - $F$ test; $\mathbf{F}_{\mathrm{c}}-F$ critical value for the test group; $\mathbf{t}$ - $t$-test; $\mathbf{t}_{\mathbf{c}}$ - the critical value of $t$ test; $p$ - probablity; the variance is the same for all the examined parameters, except for $25(\mathrm{OH}) \mathrm{D}$ and serum calcium.

age, duration of menopause, the value of vitamin $\mathrm{D}$, PTH, ionized calcium, total calcium, BMD L1-L4 in $\mathrm{g} / \mathrm{cm}^{2}$ and $t$-score, and the value of the left femoral neck BMD in $\mathrm{g} / \mathrm{cm}^{2}$ and $t$-score for both groups.

Figure 1 presents the both groups of postmenopausal women and the percentage distribution of deficiency or insufficiency of vitamin $\mathrm{D}$ in the given group. In the group of women with $\mathrm{BMD} \leq-2.5 S D$, 23 women, or $46 \%$, had the insufficiency of vitamin $\mathrm{D}$, while 27 women or $54 \%$ of them, had a deficiency of vitamin $\mathrm{D}$. In women with $\mathrm{BMD} \geq-1.0 S D$,
7 women had vitamin D insufficiency (28.6\%), while 28 of them $(71.4 \%)$ had a deficiency of vitamin D.

Out of 85 women surveyed none have had a value of vitamin $\mathrm{D}$ above $75 \mathrm{nmol} / \mathrm{L}$.

The association of vitamin $\mathrm{D}$ deficiency with values of ionized serum calcium and parathyroid hormone in women with postmenopausal osteoporosis are showen in Figures 2 and 3.

Figure 4 shows the correlation between the levels of ionized calcium $(\mathrm{mmol} / \mathrm{L})$ and the level of 25 $(\mathrm{OH}) \mathrm{D}(\mathrm{nmol} / \mathrm{L})$, measured in a group of patients 


\section{FIGURE 1}

The frequency and degree of vitamin D deficiency (nmol/L) in both groups.

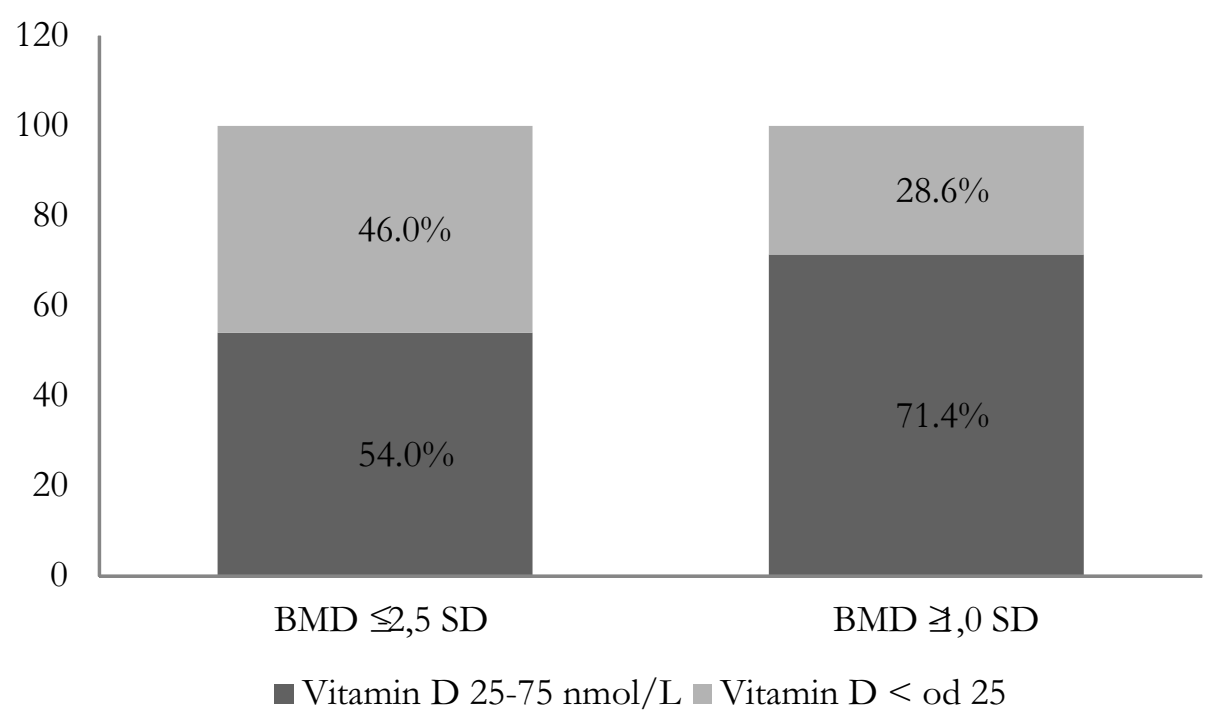

\section{TABLE 6}

Calculation of statistical significance of differences value of vitamin $D$ between the two groups.

\begin{tabular}{lccccc}
\hline & (n) 50 BMD $\leq-2.5 S D$ & (n) 35 BMD $\geq-1.0 S D$ & $\chi^{2}$ & $p$ \\
\hline Vitamin D $<25 \mathrm{nmol} / \mathrm{L}$ & 23 & 7 & 6.09 & $\mathbf{. 0 1}$ \\
\hline Vitamin D $>25 \mathrm{nmol} / \mathrm{L}$ & 27 & 28 & & \\
\hline
\end{tabular}

Legend: Fisher exact test for nominal parameters; $\chi^{2}$ - the value of Pearson's chi-sq test; $\mathbf{p}$ - probablity.

\section{FIGURE 2}

Scatter diagram of correlation values of PTH ( $\mathrm{gg} / \mathrm{mL})$, and the value of $25(\mathrm{OH}) \mathrm{D}$ (nmol / L) in the group of patients with BMD $\leq-2.5$ SD.

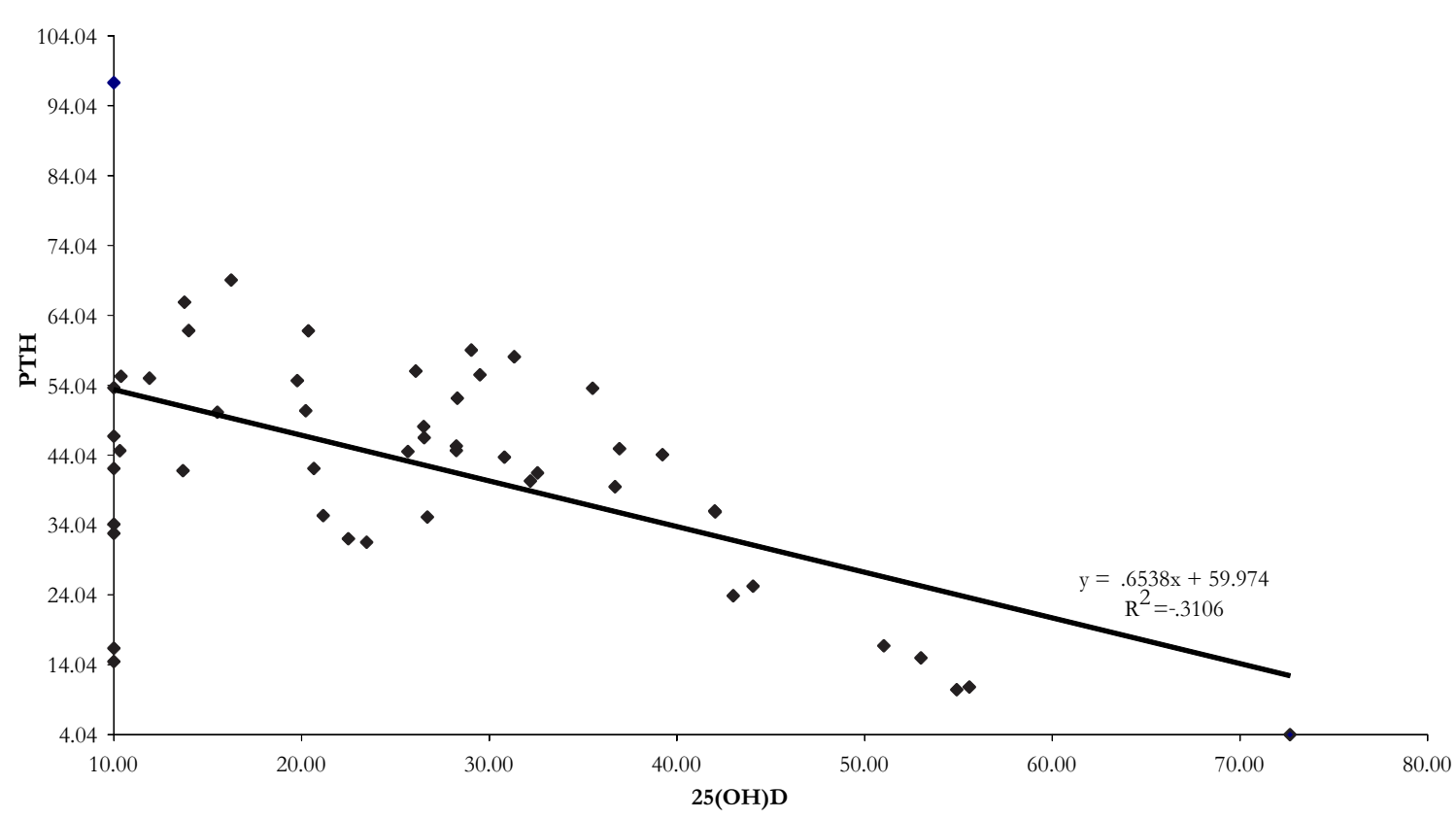




\section{FIGURE 3}

Scatter diagram of correlation of values of PTH ( $\mathrm{pg} / \mathrm{mL})$, and the value of $25(\mathrm{OH}) \mathrm{D}$ (nmol / L) in the group of subjects (n) 35 with BMD $\geq-1.0$ SD.

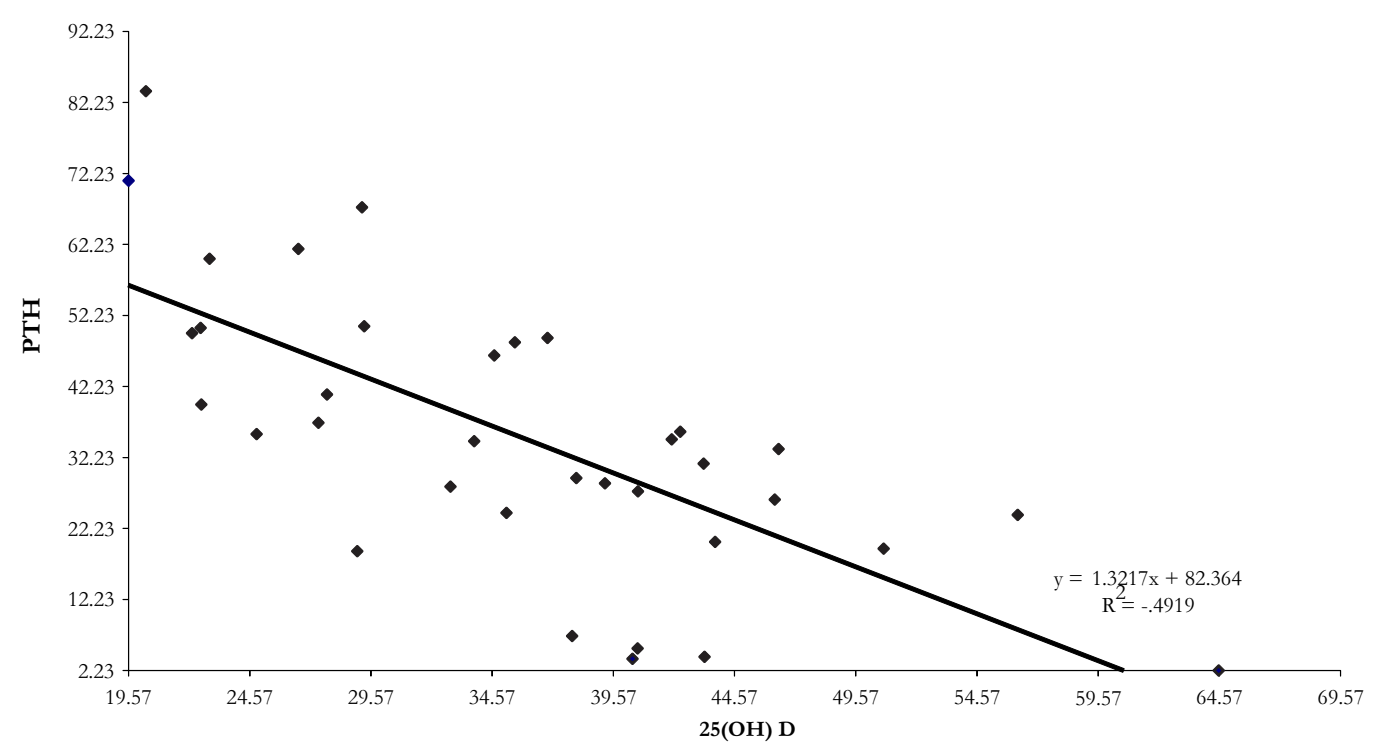

\section{FIGURE 4}

Scatter diagram of Correlation of ionized calcium (mmol L) and the value of 25 (OH) D (nmol L).

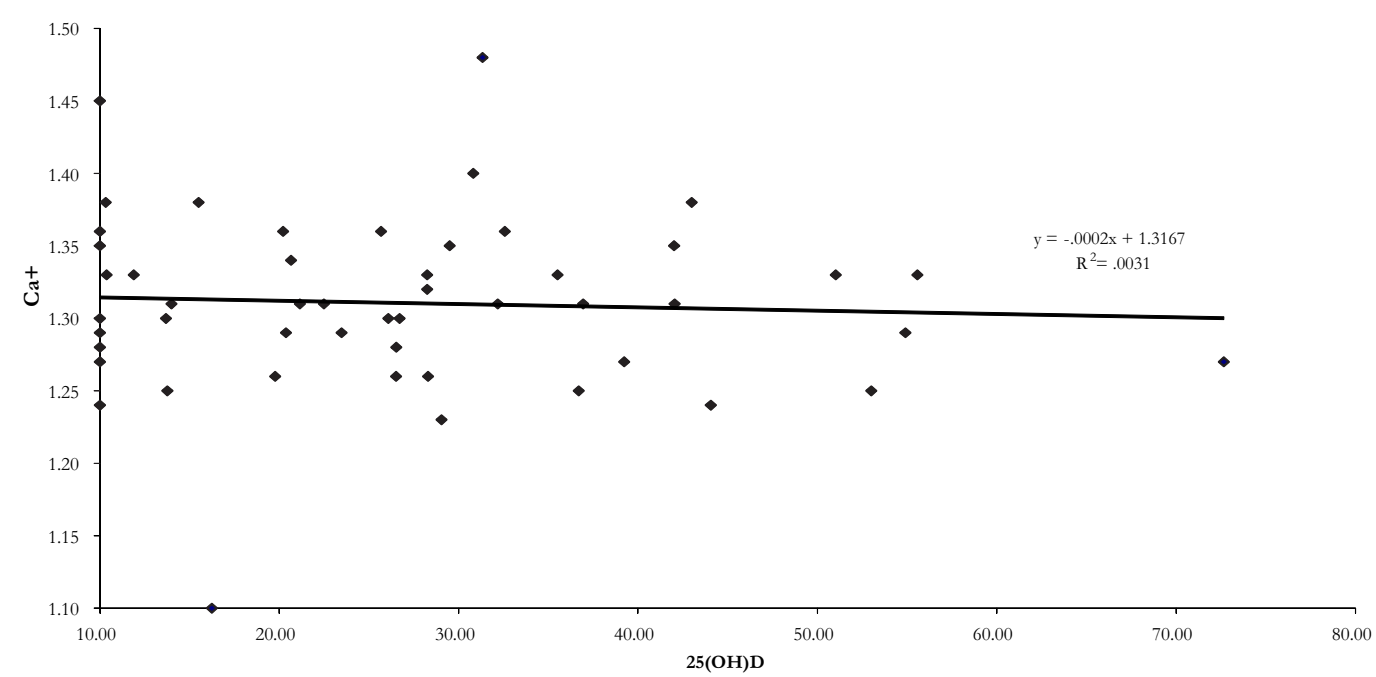

(n) 50 with $\mathrm{BMD} \leq-2.5$ SD. Very low correlation coefficient $\mathrm{R}^{2}$ of .0031 shows that there is no correlation between the examined parameters in the study group $(p>.05)$.

Figure 5 shows the correlation between the serum calcium level $(\mathrm{mg} / \mathrm{dL})$ and levels of $25(\mathrm{OH}) \mathrm{D}$ $(\mathrm{nmol} / \mathrm{L})$, measured in a group of patients $(n) 50$ with $\mathrm{BMD} \leq-2.5 S D$. Very low correlation coefficient $\mathrm{R}^{2}$ of .0077 shows that there is no correlation between the examined parameters in the study group $(p>.05)$.
The representation of the most common risk factors for osteoporotic fractures are showen in Table 7.

Figure 6 and 7 show the absolute and relative presence of risk factors in a group of patients $(n) 50$ with $\mathrm{BMD} \leq-2.5 \mathrm{SD}$ and a group of patients $(n) 35$ with $\mathrm{BMD} \geq-1.0 \mathrm{SD}$.

Table 8 shows that there is no statistically significant difference between the most common risk factors between two group of women $(p>.05)$. 


\section{FIGURE 5}

Scatter diagram of correlation values of serum calcium (mmol/L) and the value of $25(\mathrm{OH}) \mathrm{D}$ (nmol/L).

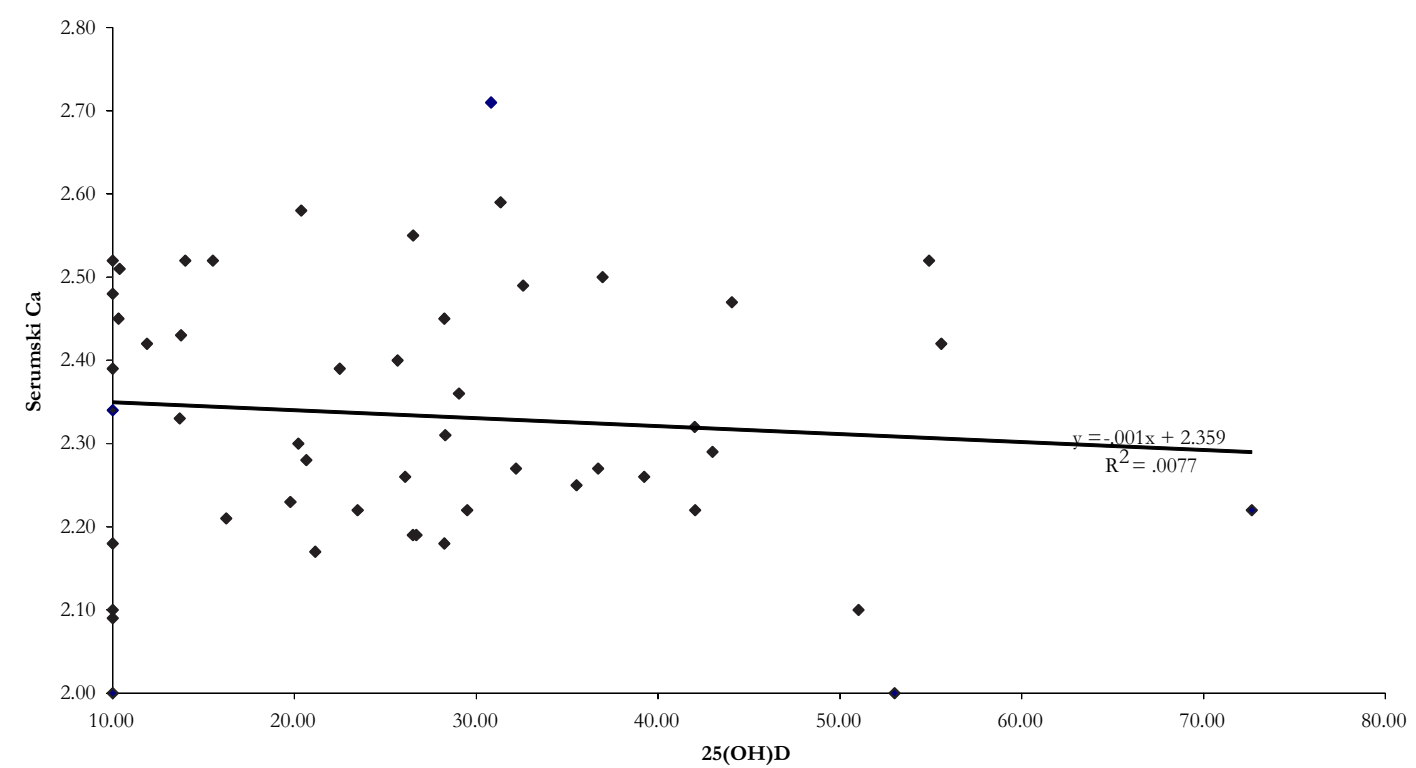

\section{TABLE 7}

Risk factors for fracture, and their absolute representation in both populations of women.

\begin{tabular}{lcc}
\hline \multicolumn{1}{c}{ Risk factors } & $B M D \leq-2,5 S D$ & $B M D \geq-1,0 S D$ \\
\hline Previous fractures in adulthood & 8 & 2 \\
\hline Fractures in first line relatives & 2 & 1 \\
\hline Very old age & 0 & 0 \\
\hline Prolonged low Ca, vitamin D and protein intake & 2 & 2 \\
\hline Tobacco smoking (over 10 cigarettes) & 7 & 3 \\
\hline BMI (body mass index) $<19$ & 1 & 0 \\
\hline Premature menopause (before age of 45.) & 9 & 3 \\
\hline Visual problems & 18 & 11 \\
\hline Lack of physical activity & 3 & 5 \\
\hline Frequent falls & 0 & 1 \\
\hline
\end{tabular}

\section{FIGURE 6}

The presence of risk factors in the group of women with

$B M D \leq-2.5$ SD presented as absolute (n) and relative (\%) values

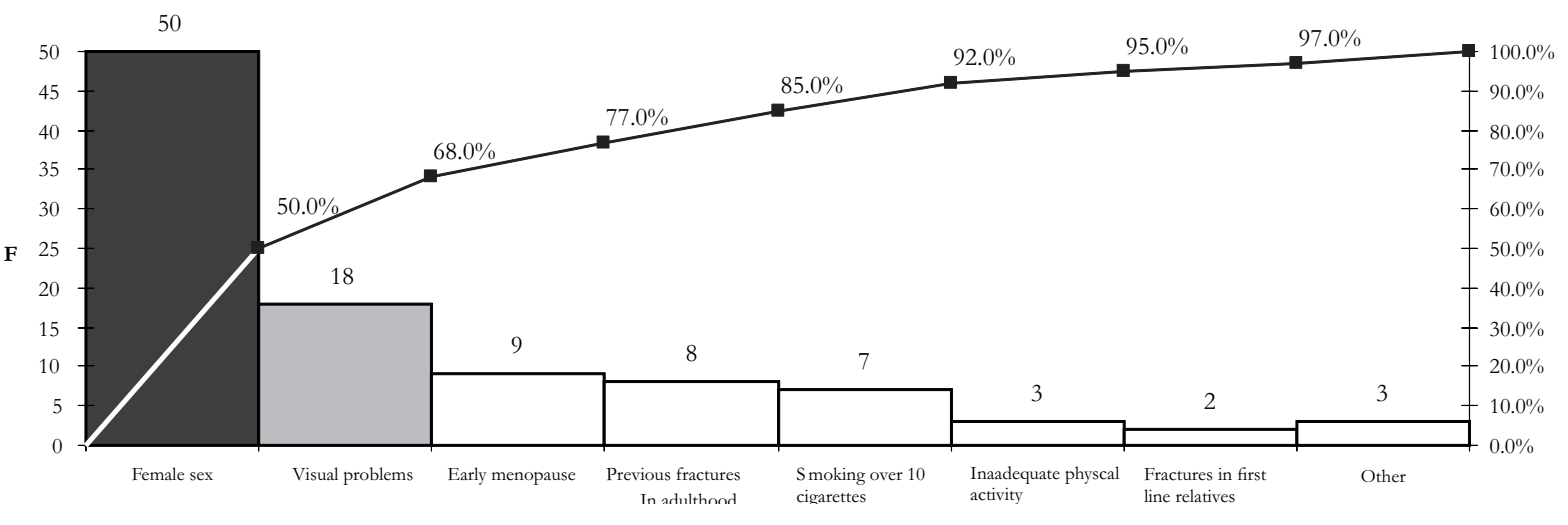


FIGURE 7

The presence of risk factors in the group of women with

$B M D \geq-1.0$ SD presented absolute (n) and relative (\%) values

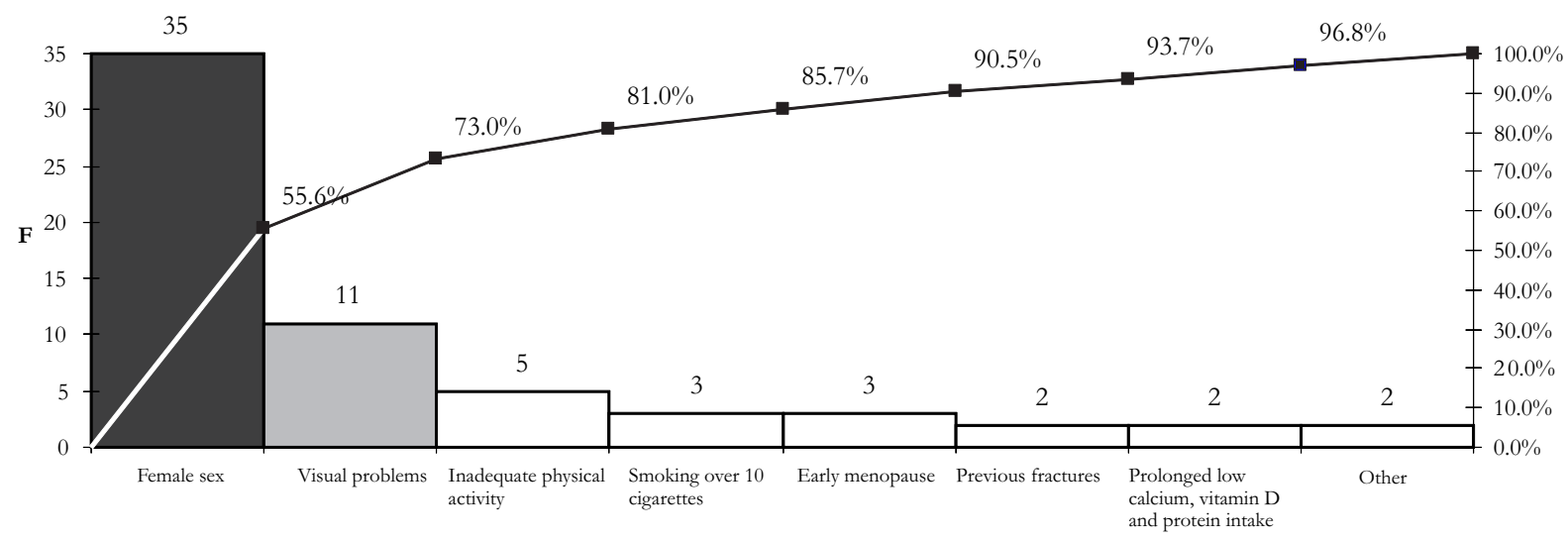

TABLE 8

Calculation of statistical significance of differences of the presence of selected risk. factors between the two groups.

\begin{tabular}{|c|c|c|c|c|c|}
\hline Risk factors & $\begin{array}{c}\text { Risk factor } \\
\text { present }\end{array}$ & $\begin{array}{c}\text { (n) } 50 \text { BMD } \leq \\
-2,5 \mathrm{SD}\end{array}$ & $\begin{array}{l}\text { (n) } 35 \mathrm{BMD} \geq \\
-1,0 \mathrm{SD}\end{array}$ & $x^{2}$ & $p$ \\
\hline \multirow{2}{*}{ Previous fractures in adulthood } & Yes & 8 & 2 & \multirow{2}{*}{.14} & \multirow{2}{*}{$p>.05$} \\
\hline & No & 42 & 33 & & \\
\hline \multirow{2}{*}{$\begin{array}{l}\text { Tobacco use (over } \\
10 \text { cigarettes a day) }\end{array}$} & Yes & 7 & 3 & \multirow{2}{*}{.44} & \multirow{2}{*}{$p>.05$} \\
\hline & No & 43 & 32 & & \\
\hline \multirow{2}{*}{ Early menopause } & Yes & 9 & 3 & \multirow{2}{*}{.21} & \multirow{2}{*}{$p^{>} .05$} \\
\hline & No & 41 & 32 & & \\
\hline \multirow{2}{*}{ Inadequate physical activity } & Yes & 3 & 5 & \multirow{2}{*}{.19} & \multirow{2}{*}{$p>.05$} \\
\hline & No & 47 & 30 & & \\
\hline
\end{tabular}

Legend: Fisher exact test for nominal parameters; $\chi^{2}$ - the value of Pearson's chi-sq test; $\mathbf{p}$ - probablity.

\section{DISCUSSION}

Loss of bone density begins with irregular menstrual cycles. Postmenopausal women may be classified into two groups according to the rate of bone loss in postmenopausal patients: the "quick" and "normal" loss of bone mass. $1 / 3$ to $1 / 4$ of women in the general population belong into the first group (Morris \& Anderson, 2010).

All the subjects covered by our study, were postmenopausal (age 50-70 yr.). The mean age of those in the group with BMD $\leq-2.5 S D$ was $61.54 \pm 5.21$ years with an average duration of menopause 12.34 \pm 5.64 years. In the group of patients with BMD $\geq$ $-1 S D$ mean age was $59.03 \pm 4.79$ years and the average duration of menopause was $7.97 \pm 6.37$ years (Table 3 and 4).

In both groups the mean value of $25(\mathrm{OH}) \mathrm{D}$ fell within deficiency range, with a group of BMD $\geq-1$ SD having a value of $25(\mathrm{OH}) \mathrm{D}$ higher than in the group of women with osteoporosis (35.67 $\pm 10,47$ $\mathrm{nmol} / \mathrm{L}$ vs $26.84 \pm 14.69 \mathrm{nmol} / \mathrm{L}$ ) (Table 3 and 4 ).

In correlation with the values of $25(\mathrm{OH}) \mathrm{D}$ as was expected the higher values of PTH were obtained with women with osteoporosis (44.34 $\pm 17.23 \mathrm{pg} /$ $\mathrm{mL}$ ) compared to women with normal DXA 35.22 $\pm 19.73 \mathrm{pg} / \mathrm{mL}$ ), although the value of PTH in both groups were within normal range (Table 3 and 4).

In both groups of subjects values of calcium in the serum, as well as ionized calcium were within normal range, except that the values of the biologically active, ionized calcium in the group of patients with $\mathrm{BMD} \leq-2.5 S D(1.31 \mathrm{mmol} / \mathrm{L})$ was lower than in the group with BMD $\geq-1 S D(1.34 \mathrm{mmol} / \mathrm{L})$ (Table 3 and 4).

By testing the studied parameters within the two groups, we obtained statistical significance for age, duration of menopause, PTH and ionized calcium ( $\phi$ $<.05)$, while for $25(\mathrm{OH}) \mathrm{D}$ we obtained strong statistical significance $(p<.01)$. 
For serum calcium we did not ind statistically significance (Table 5).

The frequency and level of vitamin D deficiency in postmenopausal women

Since 2005, a normal status of vitamin D is defined as the concentration of $25(\mathrm{OH}) \mathrm{D}>75 \mathrm{nmol} / \mathrm{L}$. Insufficiency of vitamin $\mathrm{D}$ is defined as the concentration of $25(\mathrm{OH}) \mathrm{D}<25 \mathrm{nmol} / \mathrm{L}$, vitamin $\mathrm{D}$ deficiency is defined as concentration of $25(\mathrm{OH}) \mathrm{D}$ 25-75 nmol/L and the concentration of vitamin D marked as intoxication appears when level of $25(\mathrm{OH})$ $\mathrm{D}>250 \mathrm{nmol} / \mathrm{L}$ (Aloia et al., 2006). A numerous studies have demonstrated a high prevalence of vitamin $\mathrm{D}$ deficiency in women in postmenopausal period, with the "cut of" $25(\mathrm{OH}) \mathrm{D}$ of $75 \mathrm{nmol} / \mathrm{L}$. Ofelya study, which included 669 postmenopausal women, with mean age of 62.2 years, showed that $73 \%$ of subjects had concentrations of $25(\mathrm{OH}) \mathrm{D}$ below $75 \mathrm{nmol} / \mathrm{L}$ (Sornay-Rendy, Munoz, Garnero, \& Delmas, 2005). Kuchuk, van Schoor, Pluim, Chines, and Lips (2009) published the results of the study, which was conducted in 29 countries and which included 7.441 postmenopausal women. Results of the study showed that the average concentration of 25 $(\mathrm{OH}) \mathrm{D}$ in the serum of subjects was $61.2 \mathrm{nmol} / \mathrm{L}$. Lips P. et al. (2006) in the study, which included 2.589 women with postmenopausal osteoporosis from 18 countries, showed that the prevalence of vitamin $\mathrm{D}$ insufficiency varied by region from $53.4 \%$ to $81.8 \%$. Preliminary results of a pilot study of 4 centers in Serbia have shown the insufficiency of vitamin D in $95 \%$ of women with postmenopausal osteoporosis (Anđelković, 2009).

From 2012. onward, the following values of vitamin D concentrations were recommended as a mean of classifying vitamin D status: level of $25(\mathrm{OH}) \mathrm{D}$ $>75 \mathrm{nmol} / \mathrm{L}$ was recommended as a normal level, level of $25(\mathrm{OH}) \mathrm{D} 50-75 \mathrm{nmol} / \mathrm{L}$ was considered as insufficiency, while level of $25(\mathrm{OH}) \mathrm{D} 25-50 \mathrm{nmol} / \mathrm{L}$ was considered as deficiency. Concentration of 25 $(\mathrm{OH}) \mathrm{D}<25 \mathrm{nmol} / \mathrm{L}$ was considered as severe deficiency (Jovičić, Ignatović, Beletić, Mirković, \& Majkić-Singh, 2012; Sempos, Vesper, Phinney Thienpont, \& Coates, 2012).

European multinational study included 8531 women receiving treatment for osteoporosis and showed that $80 \%$ of women had a value of $25(\mathrm{OH})$ $\mathrm{D}$ less than $80 \mathrm{nmol} / \mathrm{L}$, and about $30 \%$ of women had less than $50 \mathrm{nmol} / \mathrm{L}$ (Kanis et al., 2009; Lanyon, \& Skerry, 2001). Based on recent tests in Serbia, it was found that out of 92 postmenopausal women with osteoporosis, vitamin $\mathrm{D}$ deficiency was present in $49 \%$ (cut-off value of $25(\mathrm{OH}) \mathrm{D}$ of $50 \mathrm{nmol} / \mathrm{L}$ or less), and even $67 \%$ of respondents had lack/ shortage of vitamin D, if $75 \mathrm{nmol} / \mathrm{L} 25(\mathrm{OH}) \mathrm{D}$ was taken as a normal value (Ćirković, Petronijević, Ristić, Glišić, \& Stefanović, 2010).

Our study found a high incidence of vitamin D deficiency in both group of postmenopausal women, which is consistent with the results of numerous studies. In the group of patients with BMD $\leq-2.5$ $S D, 54 \%$ of respondents $(n=27)$ had a vitamin $\mathrm{D}$ deficiency, and $46 \%(n=23)$ lack of vitamin D. In the group of patients with BMD $\geq-1 S D, 71,4 \%$ of the patients $(n=28)$ had lack of vitamin $\mathrm{D}$, and $28.6 \%$ $(n=7)$ had vitamin $\mathrm{D}$ deficiency (Figure 1). It is interesting that none of the respondents from both groups had normal vitamin D status, if the "cut of" $25(\mathrm{OH}) \mathrm{D}$ was $75 \mathrm{nmol} / \mathrm{L}$.

By testing the significance of differences, we confirmed a statistically significant difference between the correspondent classes of vitamin D $(25(\mathrm{OH}) \mathrm{D}$ $<25 \mathrm{nmol} / \mathrm{L}$ and $25(\mathrm{OH}) \mathrm{D} 25$ to $75 \mathrm{nmol} / \mathrm{L})$ between the groups $(\phi<.01)$ (Table 6).

One of the most important factors which lead to significant bone loss in postmenopausal women is the decline in vitamin D status (Outila, Kärkkäinen, \& Lamberg-Allardt, 2001). By acting on the osteocytes, metabolites of vitamin D enhance the quality (strength and elasticity) of the bone, thus stimulating enchondral growth, thereby reducing the incidence of fractures (Roodman, 1999; Winsloe, Earl, Dennison, Cooper, \& Harvey, 2009). It appears that vitamin D increases bone formation and mineralization not only through its stimulating effect on the intestinal absorption of calcium and phosphate, but also by its effect on the differentiation of osteoblasts. Owen and colleagues have shown that vitamin $\mathrm{D}$ coordinates the sequence of the development of osteoblast-specific effects on the temporal gene expression and protein synthesis of a number of osteoblasts. It's calcemic effect 1.25 $(\mathrm{OH}) 2 \mathrm{D}$ owes to the activation of osteoclastic bone resorption, which is a secondary effect of the intermediate vitamin $\mathrm{D}$ receptor to RANKL-expressing osteoblasts (Owen, Aronow, Barone, Stein, \& Lian, 1991). Typical changes within the bones in vitamin $\mathrm{D}$ deficiency patients are: increased resorption, decreased formation, decreased production of bone matrix and reduced mineralization, leading to disorders of architecture and mechanical stability of the bone. Also, vitamin D exerts a significant effect on muscle tissue by regulating calcium metabolism within the muscle cells, which is important for the process of contraction and relaxation of muscle fibers (Cumming \& Nevitt, 1997).

Parathyroid hormone - In the last decade, numerous studies have consistently shown that for many people there is a vitamin D insufficiency, which is 
sufficient to cause an increase in serum PTH values (Aloia, Feuerman, \& Yeh, 2006). Souberbielle and associates have suggested reducing the reference values of PTH from the current $65 \mathrm{pg} / \mathrm{ml}$ to $46 \mathrm{pg} /$ $\mathrm{mL}$ (Souberbielle et al., 2001). They found that the exclusion of people with low values of vitamin D had a significant influence in determining the value of the upper reference range of PTH, and have concluded that when determining the reference values of PTH, both people with low vitamin D, and those whose values of vitamin $\mathrm{D}$ were above $25 \mathrm{nmol} / \mathrm{L}$ should be taken into account (Souberbielle et al., 2003).

Our results showed that the mean value of PTH in both groups were within normal range (Table 3 and 4), so that in this case one could speak of relative secondary hyperparathyroidism. The highest value obtained in the PTH group of patients with BMD $\leq$ -2.5SD was $97.34 \mathrm{pg} / \mathrm{mL}$ (Table 3).

Correlation analysis showed a statistically significant $(p<.01)$ negative correlation between $25(\mathrm{OH}) \mathrm{D}$ and PTH values in both groups (Figure 2 and 3).

Ionized serum calcium - an adequate intake of calcium and vitamin $\mathrm{D}$ is the first step in the prevention and treatment of osteoporosis. PTH and the active form of vitamin D (calcitriol) and to a lesser extent, sex hormones and glucocorticoids are crucial in maintaining the balance of calcium.

The analysis of our data found that the mean values and ionized serum calcium, in both groups, were within the normal range (Table 3 and 4).

Correlation analysis values of $25(\mathrm{OH}) \mathrm{D}$ and ionized calcium has shown that there is no correlation between the examined parameters in the group of women with $\mathrm{BMD} \leq-2.5 \mathrm{SD}$, which also applies to serum calcium (Figure 4 and 5).

There is evidence from clinical studies that when administered daily to women who are post-menopausal and osteoporotic, vitamin $\mathrm{D}$ not only increases bone mineral density but also reduces the risk of vertebral and non-vertebral fractures. This antifracture effect of vitamin D not only has a direct effect on bone, but also an indirect one, by increasing the muscle strength and thereby reducing the tendency to fall and the occurrence of fractures (Recker et al., 2004; Trivedi, Doll, \& Khaw, 2003).

Table 8 shows the presence of risk factors in both groups. We analyzed the most common risk factors that were present in all subjects, and then they were graphically represented and grouped as follows: previous fractures in adulthood, early menopause (before 45 years), cigarette smoking (more than 10 cigarettes a day) and insufficient physical activity (Figure 6 and 7).
Previous fractures in adulthood - in the group of patients with $\mathrm{BMD} \leq-2.5 \mathrm{SD}$, eight subjects had this risk factor. Out of these eight, seven had a value of $25(\mathrm{OH}) \mathrm{D}$ below $25 \mathrm{nmol} / \mathrm{L}$, which confirms very important role of initial serum concentration of 25 $(\mathrm{OH}) \mathrm{D}$ for anti-fracture effectiveness of vitamin D. In the group of women with normal BMD, two women have presented with this risk factor.

Early menopause - in the group of patients with $\mathrm{BMD} \leq-2.5 S D$, nine subjects had this risk factor, which was also the most common risk factor in this study group. In the group of women with normal BMD, early menopause as a risk factor was present in three respondents.

Lack of physical activity - construction and remodeling of bone tissue, and suppression of osteoclasts work, imply that physical activity is a must in the prevention and treatment of osteoporosis. In order to raise these effects, physical activity must be a regular, appropriately intense and that of appropriate sort. This has the effect not only on bone density, but also on trabecular arrangement (Peluso \& Guerra de Andrade, 2005). Exercises strengthen the muscles and improve the stability in movement, thus significantly reduce the risk of falls, particularly in the elderly, where the fall is the major risk for bone fractures. National Osteopoross Foundation sought update its consensus statement on peak bone mass. The working group has been formed and scientific literature searches from January 2000 through December 2014 were conducted with with reference to the way that lifestyle can affect the achievement of maximum bone density . The writing group concluded that there was strong evidence for the benefits of physical activity and calcium intake, moderately strong evidence for the benefits of vitamin D, and weaker evidence for the impact of other factors of lifestyle to achieve maximum bone density (Avenell, Mak, \& Connell, 2014; Weaver, 2015; ).

In the group with BMD $\leq-2.5 S D$, insufficient physical activity was represented in three respondents, and in the group with normal BMD, this risk factor was most frequent (five subjects).

Smoking of cigarettes - in the course of our research, excess nicotine use is considered smoking more than 10 cigarettes per day, given that many studies have shown that "small amounts" of nicotine have no effect on BMD (Daniel, 1972). The effect of nicotine on bone mineral density reduction is achieved through increased levels of estrogen metabolism in the liver, impaired circulation, reduced resorption of calcium and vitamin $\mathrm{D}$, and a direct action on bone cells (Deng et al., 2000). In our study, this risk factor 
was present in seven subjects in the group with BMD $\leq-2.5 \mathrm{SD}$ and in three women with normal BMD.

By testing the significance of differences of most commonly represented risk factors in both groups, we have not found statistical significance $(p>.05)$ (Table 8).

\section{CONCLUSON}

1. Large percentage of post-menopausal women had vitamin $\mathrm{D}$ deficiency

2. Women with postmenopausal osteoporosis had significantly higher vitamin $\mathrm{D}$ deficiency in relation to postmenopausal women without osteoporosis.

3. In women with postmenopausal osteoporosis vitamin $\mathrm{D}$ deficiency leads to increased levels of parathyroid hormone.

4. Level of ionized calcium was significantly lower in women with postmenopausal osteoporosis.

5. Insufficient vitamin D in postmenopausal women is an important factor contributing to the reduction of bone mineral density.

6. The high prevalence of vitamin $\mathrm{D}$ deficiency in women with postmenopausal osteoporosis supports routine determination of the value of $25(\mathrm{OH}) \mathrm{D}$ in order to select the appropriate treatment protocol.

7. Early menopause and previous fracture in adult life are the most common risk factors for osteoporotic fractures.

8. Decreased levels of vitamin D in women with postmenopausal osteoporosis leads to changes in the metabolism of calcium and parathyroid hormone.

\section{REFERENCES}

Aloia, J. F. (2001). Optimal vitamin D status and serum parathyroid hormone. BrJ Nutr, 86(1), 97-103.

Aloia, J. F., Feuerman, M., \& Yeh, J. K. (2006). Reference Range for serum Parathyroid Hormone. Endocrine Practice JournalAmerican Association of Clinical Endocrinologists, 12(2), 137-144. doi: 10.4158/EP.12.2.137; PMid: 16690460; PMCid: PMC1482827

Aloia, J. F., Talwar, S. A., Pollack, S., Feuerman, M., \& Yeh, J. K. Optemal vitamin D status and serumparathyroid hormone concentrations in African American women. Am J Clin Nutr, 84(3), 602-609.
Anđelković, Z. (2009). Značaj određivanja statusa vitamina $\mathrm{D}$ u posmenopauzalnoj osteoporozi [The significance of the status of vitamin D in postmenopause osteoporosis]. Balneoclimatologija, 33(4), 3-9.

Avenell, A., Mak, J. C., \& O'Connell, D. (2014). Vitamin D and Vitamin D analogues for preventing fractures in post-menopausal women and older men. Cochrane Database Syst Rev., 4: CD000227. doi: 10.1002/14651858.cd000227. pub4

Bischoff-Ferrari, H. A., Dawson Hughes, B., Willet, W. C., Staehelin, H. B., Bazemore, M. G., Zee, R. Y., \& Wong, J. B. (2004). Effect of vitamin D on falls. JAMA, 291(16), 1999-2006. doi: 10.1001/ jama.291.16.1999; PMid: 15113819

Bischoff-Ferrari, H. A., Willett, W. C., Wong, J. B., Giovannucci, E., Dietrich, T., \& DawsonHughes, T. (2005). Fracture prevention with vitamin $\mathrm{D}$ supplementation: a metaanalysis of randomized clinical trials. $J A M A, 293(18)$, 2257-2264. doi: 10.1001/jama.293.18.2257; PMid: 15886381

Bronner, F. (2001). Extracellular and intracellular regulation of calcium homeostasis. Sci World J, 1, 919-925. doi: 10.1100/tsw.2001.489; PMid: 12805727

Brixen, K., Abrahamsen, B., \& Kassem, M. (2005). Prevention and treatment of osteoporosis in women. Current Obstetrics \& Gynaecology, 15, 251258. doi: 10.1016/j.curobgyn.2005.05.003

Canalis, E. (2010). Update in new anabolic therapies for osteoporosis. J Clin Endocrinol Metab, 95(4), 1496-1504. doi: 10.1210/jc.20092677; PMid: 20375217; PMCid: PMC2853988

Cooper, A. L. (2006). Improved patient persistence on once-monthly dosing regime plus patient support compared with a weekly dosing regime Abstract P798MO. In IOF World Congress on Osteoporosis. Toronto, Canada.

Cosman, F., deBeur, S. J., LeBoff, M. S.. Lewiecki, E. M., Tanner, B., Randall, S., \& Lindsay, R. (2014). Clinical GUide to Prevention and Treatment of Osteoporosis. Osteoporosis Int, 25, 2359-2381. doi: 10.1007/s00198-014-2794-2; PMid: 25182228 ;PMCid: PMC4176573

Cumming, R. G., \& Nevitt, M. C. (1997). Calcium for prevention of osteoporotic fractures in postmenopausal women. J Bone Miner Res, 13, 1530-1538. doi: 10.1359/jbmr.1997.12.9.1321

Ćirković, M., Petronijević, M., Ristić, G., Glišić, B., \& Stefanović, D. (2010). Značaj određivanja koncentracije vitamina $\mathrm{D}$ u prevenciji preloma kod postmenopauzalnih žena [The significance 
of determining the concentration of vitamin $\mathrm{D}$ in the prevention of fractures in postmenopausal women]. Acta Rheumatologica Belgradensia, 40(2), 124

Daniel, H. W. (1972). Osteoporosis and smoking. JAMA, 221-240. doi: 10.1001/ jama.1972.03200180051022; doi: 10.1001/ jama.221.5.509b

Dawson-Hughes, B., Heaney, R. P., Holick, M. F., Lips, P., Meunier, P. J., \& Vieth, R. (2005). Estimates of optimal vitamin D status. Osteoporosis Int, 16(7), 713-716. doi: 10.1007/ s00198-005-1867-7; PMid: 15776217

Deng, H., Chen, W., Conway, T., Zhou, Y., Daves, K. M., Stegman, M. R., ... Recker, R. R. (2000). Determination of bone mineral density of the hip and spine in human pedigrees by genetic and life-style factors. Genetic Epidemiology, 19, 160-167. doi: 10.1002/1098-2272(200009) 19:2<160::AID-GEPI4>3.0.CO;2-H

Ettinger, P. M. (2003). Aging bone and osteoporosis. Archives of Internal Medicine, 163(18), 2237-2246. doi: 10.1001/ archinte.163.18.2237; PMid: 14557222

Feskanich, D., Willett, W., \& Colditz, G. (2002). Walking and leisure-time activity and risk of hip fracture in postmenopausal women. $J A M A$, 288(18), 2300-2306. doi: 10.1001/ jama.288.18.2300; PMid: 12425707

Grand, A. M., Avenell, A., Campbell, M. K., McDonald, A. M., MacLennan, G. S., McPherson, G. C., ... Wallace, W. A. (2005). Oral vitamin D3 and calcium for secondary prevention of low trauma fractures in elderly people (Randomised Evaluation of Calcium or Vitamin D, RECORD): A randomised placebocontrolled trial. Lancet, 365(9471), 1621-1628. doi: 10.1016/S0140-6736(05)63013-9

Greiwe, J. S., Cheng, B., Rubin, D. C., Yarasheski, K. E., \& Semenkovch, C. F. (2001). Resistance exercise decreases skeletal muscle tumor necrosis factor in frail elderly humans. FASEB J, 15(2), 475-482. doi: 10.1096/fj.00-0274com; PMid: 11156963

Holick, M. F. (2007). Vitamin D deficiency. N Engl J Med, 357(3), 266-281. doi: 10.1056/ NEJMra070553; PMid: 17634462

Iqbal, M. M. (2000). Osteoporosis: epidemiology, diagnosis and treatment. South Med J, 93, 2-18. doi: 10.1097/00007611-200001000-00001; doi: 10.1097/00007611-200093010-00002; PMid: 10653058

Jackson, R. D., LaCroix, A. Z., Gass, M. Wallace, R. B., Robbins, J., Lewis, C. E., ... Barad, D. (2006).
Calcium plus vitamin D supplementation and risk of fractures. $\mathrm{N}$ Engl J Med, 354, 669-683. doi: 10.1056/NEJMoa055218; PMid: 16481635

Jovičić, S., Ignatović, S., Beletić, A., Mirković, D., \& Majkić-Singh, N. (2012). Poređenje tri različite metode za odredivanje $25(\mathrm{OH}) \mathrm{D}$ i statusa vitamina $\mathrm{D}$ u opštoj populaciji [Comparison of three different methods for the determination of $25(\mathrm{OH}) \mathrm{D}$ and vitamin $\mathrm{D}$ status in the general population]. Journal of Medical Bichemistry; 31(4), 347-357.

Kanis, J. A., Olden, A., Johansson, H., Borgstrom, F., Storm, O., \& McCloskey, E. (2009). FRAX its applications to clinical practice. Bone, 44(5), 734-743. doi: 10.1016/j.bone.2009.01.373; PMid: 19195497

Kuchuk, N. O., van Schoor, N. M., Pluim, S. M., Chines, A., \& Lips, P. (2009). Vitamin D status, parathyroid function, bone turnover, and BMD in postmenopausal women with osteoporosis: global perspective. J Bone Mener res, 24(4), 693 701. doi: 10.1359/jbmr.081209; PMid: 19049341

Lanyon, L., \& Skerry, T. (2001). Postmenopausal osteoporosis as a failure of bone's adaptation to functional loading: a hypothesis. J Bone Miner Res., 16(11), 1937-1947. doi: 10.1359/ jbmr.2001.16.11.1937; PMid: 11697789

Lips, P. (2006). Vitamin D physiology. Prog Biophys Mol Biol, 92(1), 4-8. doi: 10.1016/j. pbiomolbio.2006.02.016; PMid: 16563471

Lips, P., Hosking, D., Lippuner, K., Norquist, J. M., Wehren, L., Maalouf, G., ... Chandler, J. (2006). The prevalence of vitamin D inadequacy amongst women with osteoporosis: an international epidemiological investigation. $J$ Intern Med, 260, 245-254. doi: 10.1111/j.1365-2796.2006.01685.x; PMid: 16918822

McCloskey, E. (2006). Using risk factors for diagnosis ond treatment of osteoporosis. Osteoporosis Int, 17(12), 112-115.

Morris, H. A., \& Anderson, P. H. (2010). Autocrine and paracrine action of Vitamin D. Clin Biochem Rev, 31(4), 129-138. PMid: 21170259; PMCid: PMC2998276

National Osteoporosis Foundation. (2003). Physicians guide to prevention and treatment of osteoporosis. Washington, DC: National Osteoporosis Foundation (NOF).

National Osteoporosis Foundation. (2015). Interdisciplinary symposium on osteoporosis. Washington, DC: National Osteoporosis Foundation (NOF). 
Nuti, R., Bianchi, G., Brandi, M. L., Caudarella, R., Derasmo, E., Fiore, C., ... Ortolani, S. (2009). Superiority of alfacalcidol compared to vitamin $\mathrm{D}$ plus calcium in lumbal bone mineral density in postmenopausal osteoporosis. Rheumatol Int, 26(5), 445-453. doi: 10.1007/s00296-005-00734; PMid: 16283320

Outila, T. A., Kärkkäinen, M. U., \& LambergAllardt, C. J. (2001). Vitamin D status affects serum concentrations during winter in female adolescents: associations with forearm BMD. Am J Clin Nutr, 74(2), 206-210. PMid: 11470722

Owen, T. A., Aronow, M. S., Barone, L. M., Stein, G. S., \& Lian, J. B. (1991). Pleiotropic effects of vitamin $\mathrm{D}$ on osteoblast gene expression are related to proliferative and differentiated state of the bone cell phenotype: dependency upon basal levels of gene expression, duration of exposure, and bone matrix competency in normal rat osteoblast cultures. Endocrinology, 128, 1496-1504. doi: 10.1210/endo-128-3-1496; PMid: 1999168

Richard, J. B, Rivadeneira, F., Inouye, M., Pastinen, T. M., Soranzo, N., Wilson, S. G. ... Hart, P. (2008). Bone mineral density, osteoporosis and osteoporotic fractures: a genome wide association study. Lancet; 371(9623), 1505-1512. doi: 10.1016/S0140-6736(08)60599-1

Panneman, M. J., Lips, P., Sen, S. S., \& Herings R. M. (2004). Undertreatment with anti osteoporotic drugs after hospitalsation for fracture. Osteoporosis Int, 15(2), 120-124. doi: 10.1007/s00198-003-1544-7; PMid: 14618302

Peacock, M., Selby, P. L., Francis, R. M., Brown, W. B., \& Hordon, L. (1985). Vitamin D deficiency, insufficiency, sufficiency and intoxication. What do they mean?. In A.W. Norman, K. Schaefer, H. G. Grigoleit, \& D. V. Herrath (Eds.), Vitamin D: Chemical, biochemical and clinical update (pp. 569-570). Berlin, Germany: Walter de Gruyter.

Peluso, M. A., \& Guerra de Andrade, L. H. S.

(2005). Physical activity ond mental haelth: the assotiation betveen exercise and mood. Clinics., 60(1), 61-70. doi: 10.1590/S1807-

59322005000100012; PMid: 15838583

Pilipović, N., Branković, S., \& Vujasinović, N. (2005). Koštana masa i prelomi kostiju kod stanovnika Beograda [Bone mass and bone fractures in the population of Belgrade]. Acta Rheum Belgr, 35(1), 35-39.

Recker, R. R., Stakkestad, J. A., Chesnut, C. H., Christiansen, C., Skag, A., Hoiseth, A., ...
Delmas, P. D. (2004). Insufficiently dose intravenous ibandronate injections are associated with suboptimal antifracture efficacy in postmenopausal osteoporosis. Bone, 34(5), 890-899. doi: 10.1016/j.bone.2004.01.008; PMid: 15121021

Roodman, G. D. (1999). Cell biology of the osteoclast. Exp Hemat, 27(8), 1229-1231. doi: 10.1016/S0301-472X(99)00061-2

Sempos, C. T., Vesper, H. W., Phinney Thienpont, L. M., \& Coates, P. M. (2012). Vitamin D status as an international issue: National surveysand the problem standardization. Scand J Clin Lab Invest, 243, 32-40.

Shoback, D., Marcus, R., Bikle, D., \& Strewler, G. J. (2001). Mineral metabolism and metabolic bone disease. In F. S. Greenspan \& D. G. Gardner (Eds.), Basic and Clinical Endocrinology (pp 485493). New York, NY: McGraw-Hill.

Siris, S. E. (2004). Bone health menopause: Assessing who is at risk of developing osteoporosis. In Satellite Symposium at IOF World Congress on Osteoporosis (pp. 7-8). Rio De Janeiro, Brazil: International Osteoporosis Foundation.

Sornay-Rendy, E., Munoz, F., Garnero, P., \& Delmas, P. D. (2005). Identification of osteopenic women at high risk of fracture: The OFELY study. J Bone Mener Res, 20(10), 18131819. doi: 10.1359/JBMR.050609; PMid: 16160738

Souberbielle, J. C., Cormier, C., Kindermans, C, Gao, P., Cantor, T., Forette, T., \& Baulieu, E. E. (2001). Vitamin D status and redefining serum parathyroid hormone reference range in the elderly. J Clin Endocrinol Metab., 86(7), 30863090. doi: 10.1210/jcem.86.7.7689; doi: 10.1210/jc.86.7.3086; PMid: 11443171

Souberbielle, J. C., Lawson-Body, E., Hammadi, B., Sarfati, E., Kahan, A., \& Cormier, C. (2003). The use in clinical practice of parathyroid hormone normative values established in vitamin D-sufficient subjects. J Clin Endocrinol Metab., 88(8), 3501-3504. doi: 10.1210/jc.2003030097; PMid: 12915625

Stefanović, D., Zečević, R., \& Petronijević, M. (2009). Vitamin D $i$ analozi za zdrave kosti, za zdrav život [Vitamin D and analogues for healthy bones, for healthy life]. Belgrade, Serbia: Actavis trading.

Stevenson, J. C., \& Marsh, M. S. (2007). An atlas of osteoporosis. 3rd edition. London, Unred Kngdom: Informa UK Ltd. doi: 10.3109/9780203090848 
Sweet, M. G., Jeremiah, M. P., \& Galazka, S. S. (2009).Diagnosis and treatment of osteoporosis. Am Fam Physician, 79(3), 193-200. PMid: 19202966

Trivedi, D., Doll, R., \& Khaw, E. (2003). Effects of fourly oral vitamin D supplementation on fractures ond mortality in men and women living in the community: randomised double blind controlled trial. BMJ, 326(7387), 469-475. doi: 10.1136/bmj.326.7387.469; PMid: 12609940; PMCid: PMC150177

Tuck, S. P., \& Francis, R. M. (2002). Osteoporosis. Postgrad Med J, 78(923), 526-532. doi: 10.1136/ pmj.78.923.526; PMid: 12357012; PMCid: PMC1742482

Vieth, R, \& Fraser, D. (2002). Vitamin D insufficiency: No RDA exists for this nutrient. Can Med Assoc J, 166(12), 1541-1542.
WHO. (1994). Study Group on assessment of fracture risk and application to screening for postmenopausal osteoporosis. Report of WHO study group. Geneva, Switzerland: WHO Technical Report Series, 1-129.

Weaver, C. M. (2015). Parellels between nutrition and physical activity: research questions in development of peak bone mass. Res $Q$ Exerc Sport, 86(2), 103-106. doi: 10.1080/ 02701367.2015.1030810; PMid: 25965111

Winsloe, C., Earl, S., Dennison, E. M., Cooper, C., \& Harvey, N. C. (2009). Early life factors in the pathogenesis of osteoporosis. Curr Osteoporos Rep., 7(4), 140-144. doi: 10.1007/s11914-0090024-1; PMid: 19968918

Zizic T. (2004). Pharmacologic prevention of osteoporotic fractures. Am Fam Physician, 70(7), 1293-3000. PMid: 15508540

Received: Febreuary 19, 2015 Revision received: May 28, 2015 Accepted: Jun 25, 2015

Correspondence to: Tatjana Milivojac, MSc School of Medicine Save Mrkalja 14 78000 Banja Luka Bosnia and Herzegovina Phone: 0038765823084 E-mail: tatjanamilivojac@yahoo.com 